\title{
KEMAMPUAN REPRESENTASI MATEMATIK PADA MATERI SEGI EMPAT SISWA SMP KELAS VII
}

\begin{abstract}
This study aims to determine the ability of mathematical representation of the level of basic ability of students in the rectangular material. The research method used is descriptive. The subject of the research is VII grade SMPN in Karawang. The results of the data analysis showed that the students' upper ability level with the percentage of $83 \%$, had high visual representation ability, medium symbol representation ability, medium verbal representation ability. Students with a middle-level skill level of $72 \%$, have medium visual representation, medium symbol representation ability, and low verbal representation ability. Students with lower base ability level with $50 \%$ percentage, medium moderate representation ability, low symbol representation ability, very low verbal representation ability.
\end{abstract}

Keywords: Mathematical Representation, Rectangle

\begin{abstract}
Abstrak
Penelitian ini bertujuan untuk mengetahui kemampuan representasi matematis dari tingkat kemampuan dasar siswa pada materi segi empat. Metode penelitian yang digunakan adalah deskriptif. Subjek penelitian adalah kelas VII SMPN di Karawang. Hasil analisis data menunjukkan bahwa siswa tingkat kemampuan dasar atas dengan persentase $83 \%$, memiliki kemampuan representasi visual tinggi, kemampuan representasi simbol sedang, kemampuan representasi verbal sedang. Siswa tingkat kemampuan dasar menengah dengan persentase $72 \%$, memiliki kemampuan representasi visual sedang, kemampuan representasi simbol sedang, dan kemampuan representasi verbal rendah. Siswa tingkat kemampuan dasar bawah dengan persentase 50\%, memiliki kemampuan representasi visual sedang, kemampuan representasi simbol rendah, kemampuan representasi verbal sangat rendah.
\end{abstract}

Kata Kunci: Kemampuan Representasi, Segi Empat

How to cite: Nurpadilah, E., Rohaeti, E.E., \& Afrilianto, M. (2018). Kemampuan Representasi Matematik Pada materi Segiempat Siswa SMP Kelas VII. JPMI - Jurnal Pembelajaran Matematika Inovatif, 1 (4), 765-772.

\section{PENDAHULUAN}

Pendidikan Dalam kurikulum tingkat satuan pendidikan (KTSP) dinyatakan bahwa mata pelajaran matematika perlu diberikan kepada semua peserta didik mulai dari sekolah dasar untuk membekali peserta didik, kemampuan berpikir logis, analitis, sistematis, kritis dan kreatif, serta kemampuan bekerja sama (Effendi, 2012). Hal ini sesuai dengan pendapat Afrilianto (2014) dalam perkembangan ilmu pengetahuan dan teknologi, matematika sebagai salah satu disiplin ilmu dalam dunia pindidikan mempunyai peranan yang besar. Matematika bermanfaat dalam perkembangan berbagai ilmu pengetahuan lainnya. Oleh karena itu, diperlukan penguasaan matematika sejak dini dan matematika harus dipelajari pada semua jenjang pendidikan, agar kemampuan siswa berkembang sesuai dengan tuntutan kehidupan di masa yang akan datang. Matematika merupakan pengetahuan universal yang mendasari 
perkembangan teknologi modern di setiap zaman dan memiliki peranan penting dalam kehidupan manusia (Moka, Hendriana, \& Afrilianto, 2018). Menurut Wahyudin (Rohaeti, 2012) bahwa salah satu penyebab siswa lemah dalam matematika adalah kurang memiliki kemampuan untuk memahami (pemahaman) untuk mengenali konsep-konsep dasar matematika (aksiomatik, definisi, kaidah dan teorema) yang berkaitan dengan pokok bahasan yang sedang dibicarakan. Dari pemaparan fakta ini, perlu adanya pembelajaran yang mengkondisikan siswa aktif dalam belajar matematika. Untuk mengembangkan kemampuan matematis siswa, maka pembelajaran harus menjadi lingkungan dimana siswa mampu terlibat secara aktif dalam banyak kegiatan matematika yang bermanfaat (Laila, Hidayat, \& Hendriana, 2018).

Tujuan yang diharapkan dalam pembelajaran matematika oleh NCTM (Effendi, 2012) menetapkan lima standar kemampuan matematik yang harus dimiliki oleh siswa, yaitu kemampuan pemecahan masalah matematik (problem solving), kemampuan komunikasi matematik (communication), kemampuan koneksi matematik (connection), kemampuan penalaran (reasoning) dan kemampuan representasi (representation). Menurut Rohaeti (2012) , dalam kehidupan sehari-hari, matematika selalu dapat kita temui mulai dari matematika yang sederhana hingga yang kompleks. Matematika sebagai ilmu pengetahuan yang diperoleh dari bernalar adalah suatu ilmu dasar dan salah satu disiplin ilmu yang sangat besar pengaruhnya terhadap kemajuan dan perkembangan ilmu pengetahuan. Matematika dikenal sebagai ilmu dasar, pembelajaran matematika melatih kemampuan kritis, logis, analitis dan sistematis (Moka, Hendriana \& Afrilianto, 2018) .

Menurut Rohaeti (2012), karena konsep matematika tersusun secara hierarkis, terstruktur, logis, dan sistematis mulai dari konsep yang paling sederhana sampai pada konsep yang paling kompleks. Dalam pembelajaran matematika guru seharusnya menyiapkan kondisi siswanya agar mampu menguasai konsep-konsep yang akan dipelajari mulai dari yang sederhana sampai yang lebih kompleks. Hal ini sesuai dengan pendapat Hutagaol (2013) menyebutkan representasi matematis yang dimunculkan oleh siswa merupakan ungkapan-ungkapan dari gagasan-gagasan atau ide matematika yang ditampilkan siswa dalam upayanya untuk memahami suatu konsep matematika ataupun dalam upayanya untuk mencari sesuatu solusi dari masalah yang sedang dihadapinya. Menurut Mandur, Sadra, \& Suparta (2013) menyatakan bahwa guru kurang memberikan kesempatan kepada siswa untuk menghadirkan dan menggunakan kemampuan representasi matematiknya, sehingga siswa cenderung mengikuti langkah-langkah yang dibuat gurunya.

Pentingnya kemampuan representasi matematik dapat dilihat dari standar representasi yang ditetapkan oleh NCTM. NCTM (Effendi, 2012) menetapkan bahwa program pembelajaran dari pra-taman kanak-kanak sampai kelas 12 harus memungkinkan siswa untuk: (1) menciptakan dan menggunakan representasi untuk mengorganisir, mencatat, dan mengkomunikasikan ideide matematis; (2) memilih, menerapkan, dan menerjemahkan representasi matematis untuk memecahkan masalah; dan (3) menggunakan representasi untuk memodelkan dan menginterpretasikan fenomena fisik, sosial, dan fenomena matematis. Dengan demikian, kemampuan representasi matematis diperlukan siswa untuk menemukan dan membuat suatu alat atau cara berpikir dalam mengkomunikasikan gagasan matematis dari yang sifatnya abstrak menuju konkret, sehingga lebih mudah untuk dipahami. Representasi memiliki peranan penting dalam pembelajaran matematika karena dengan representasi peserta didik akan lebih mudah dalam mengomunikasikan ide-ide matematis sehingga masalah-masalah matematis yang diberikan dapat diselesaikan dengan baik. 


\section{METODE}

Penelitian ini adalah penelitian kualitatif dengan metode deskriptif. Penelitian deskriptif adalah suatu metode penelitian yang ditujukan untuk menggambarkan fenomena-fenomena yang ada, yang berlangsung pada saat ini atau saat yang lampau. Penelitian ini tidak mengadakan manipulasi atau pengubahan pada variabel-variabel bebas, tetapi menggambarkan suatu kondisi apa adanya. Penggambaran kondisi bisa individual atau kelompok, dan menggunakan angkaangka. Tujuan dari penelitian ini adalah untuk mendeskripsikan kemampuan representasi matematika siswa pada materi segi empat. Kemampuan representasi matematik siswa dalam menyelesaikan soal-soal segi empat akan diamati atau diteliti secara alamiah berdasarkan tes tertulis dan hasil wawancara kemudian akan dianalisis secara mendalam. Data yang telah diperoleh kemudian dikumpulkan, dirangkum, diperiksa kebenarannya, lalu diinterpretasikan sehingga menjadi suatu informasi yang bermakna. Subjek Penelitian adalah siswa kelas VII di SMPN di Karawang. Prosedur dalam penelitian ini ada 3 tahap, yaitu : 1) tahap persiapan, dalam tahap persiapan peneliti melakukan beberapa hal diantaranya, melakukan pra riset kepada sample (siswa), menyiapkan instrumen soal kemampuan representasi matematis. 2) tahap pelaksanaan, memberikan tes kepada siswa, menganalisa hasilnjawaban. 3) tahap akhir, dalam tahap akhir peneliti menganalisis data, mendeskripsikan hasil penelitian dan menyusun laporan penelitian. Kemampuan representasi matematis siswa dinilai berdasarkan kriteria pada Tabel 1.

Tabel 1. Pedoman Penskoran Kemampuan Representasi Matematik

\begin{tabular}{|c|c|c|}
\hline Aspek yang Dinilai & Respon Siswa terhadap Soal/Masalah & Skor \\
\hline \multirow{3}{*}{$\begin{array}{l}\text { 1. Menyajikan data atau informasi } \\
\text { dari suatu masalah ke } \\
\text { representai gambar, diagram, } \\
\text { grafik atau tabel. }\end{array}$} & $\begin{array}{l}\text { a. Data atau informasi yang dapat disajikan } \\
\text { ke representasi gambar, diagram, grafik, } \\
\text { atau tabel salah }\end{array}$ & 1 \\
\hline & $\begin{array}{l}\text { b. Menyajikan data/informasi ke } \\
\text { representasi gambar, diagram, grafik, } \\
\text { atau tabel hampir benar/mendekati } \\
\text { benar. }\end{array}$ & 2 \\
\hline & $\begin{array}{l}\text { c. Menyajikan data/informasi ke } \\
\text { representasi gambar, diagram, grafik, } \\
\text { atau tabel benar. }\end{array}$ & 3 \\
\hline \multirow[t]{3}{*}{$\begin{array}{l}\text { 2. Menyelesaikan masalah yang } \\
\text { melibatkan ekspresi matematis. }\end{array}$} & $\begin{array}{l}\text { a. Menyelesaikan masalah } \text { yang } \\
\text { melibatkan eskpresi matematis tetapi } \\
\text { penyelesaian salah. }\end{array}$ & 1 \\
\hline & $\begin{array}{l}\text { b. Menyelesaikan masalah yang } \\
\text { melibatkan eskpresi matematis tetapi } \\
\text { penyelesaian kurang benar. }\end{array}$ & 2 \\
\hline & $\begin{array}{l}\text { c. Menyelesaikan masalah yang } \\
\text { melibatkan eskpresi matematis dengan } \\
\text { benar. }\end{array}$ & 3 \\
\hline \multirow{3}{*}{$\begin{array}{l}\text { 3. Menuliskan langkah-langkah } \\
\text { penyelesaian masalah } \\
\text { matematika dengan kata-kata. }\end{array}$} & $\begin{array}{l}\text { a. Hanya sedikit penjelasan (hanya } \\
\text { diketahui dan ditanya). }\end{array}$ & 1 \\
\hline & $\begin{array}{l}\text { b. Penjelasan secara matematis tetapi tidak } \\
\text { tersusun secara logis. }\end{array}$ & 2 \\
\hline & $\begin{array}{l}\text { c. Penjelasan secara matematis dengan } \\
\text { jelas dan tersusun secara logis.. }\end{array}$ & 3 \\
\hline
\end{tabular}




\section{HASIL DAN PEMBAHASAN}

\section{Hasil}

Penelitian ini dilaksanakan pada salah satu kelas VII di salah satu SMP negeri yang ada di Karawang. Dari kelas VII SMPN di Karawang, dipilih secara acak satu kelas yaitu kelas VII sebanyak 6 orang siswa sebagai subjek penelitian. Siswa diberikan soal tes kemampuan representasi matematis.

Hasil tes kemampuan representasi matematis berdasarkan aspek representasi matematis (representasi visual, representasi simbol, representasi verbal) ditinjau dari tingkat kemampuan dasar siswa dapat dilihat pada Tabel 2 dan Tabel 3 berikut ini :

Tabel 2. Datta Hasil Penelitian

\begin{tabular}{|c|c|c|c|c|c|c|c|c|}
\hline \multirow{2}{*}{ Subjek } & \multicolumn{6}{|c|}{ Jumlah skor (Soal) } & \multirow{2}{*}{ Jumlah } & \multirow{2}{*}{$\begin{array}{l}\text { Persentase } \\
\%\end{array}$} \\
\hline & 1 & 2 & 3 & 4 & 5 & 6 & & \\
\hline 1 & 3 & 2 & 3 & 2 & 3 & 2 & 15 & $83 \%$ \\
\hline 2 & 2 & 1 & 2 & 1 & 2 & 1 & 9 & $50 \%$ \\
\hline 3 & 2 & 2 & 1 & 3 & 3 & 2 & 13 & $72 \%$ \\
\hline 4 & 3 & 2 & 2 & 2 & 3 & 3 & 15 & $83 \%$ \\
\hline 5 & 3 & 2 & 2 & 2 & 2 & 2 & 13 & $72 \%$ \\
\hline 6 & 3 & 2 & 3 & 2 & 2 & 1 & 13 & $72 \%$ \\
\hline
\end{tabular}

Tabel 3. Hasil Tes Kemampuan Representasi Matematis

\begin{tabular}{|c|c|c|c|c|}
\hline \multirow{2}{*}{$\begin{array}{l}\text { Tingkat } \\
\text { Kemampuan } \\
\text { Siswa }\end{array}$} & \multicolumn{3}{|c|}{ Kemampuan Represenatsi } & \multirow[b]{2}{*}{ Verbal } \\
\hline & Dasar & Visual & Simbol & \\
\hline Atas & & Tinggi & Sedang & Sedang \\
\hline Menengah & & Sedang & Sedang & Rendah \\
\hline Bawah & & Sedang & Rendah & Sangat Rendah \\
\hline
\end{tabular}

Siswa yang kemampuan dasarnya berada di kelompok atas berjumlah 2 orang siswa dengan persentase $83 \%$, setelah diberikan tes kemampuan representasi matematis kelompok ini memiliki kemampuan representasi visual dikategori tinggi, representasi simbol dikategori sedang dan representasi verbal dikategori sedang. Siswa yang kemampuan dasarnya berada di kelompok menengah berjumlah 3 orang siswa dengan persentase $72 \%$, setelah diberikan tes kemampuan representasi matematis kelompok ini memiliki kemampuan representasi visual dikategori sedang, representasi simbol dikategori sedang dan representasi verbal dikategori rendah. Siswa yang kemampuan dasarnya berada di kelompk menengah, Siswa yang kemampuan dasarnya berada di kelompok bawah berjumlah 1 orang siswa dengan persentase $50 \%$, setelah diberikan tes kemampuan representasi matematis kelompok ini memiliki 
kemampuan representasi visual dikategori sedang, representasi simbol dikategori rendah dan representasi verbal dikategori sangat rendah.

\section{Pembahasan}

Tes kemampuan representasi matematis yang diberikan berbentuk essay, terdiri dari 6 soal dengan 3 jenis, yaitu soal visual ( nomor 1 dan nomor 5), soal simbol (nomor 4 dan nomor 2) dan soal verbal (soal nomor 3 dan nomor 6). Siswa yang berada pada tingkat kemampuan dasar kelompok atas berjumlah 2 orang siswa, pada kelompok menengah berjumlah 3 orang dan pada kelompok bawah berjumlah 1 orang.

Siswa yang kemampuan dasarnya tinggi, yaitu dilihat dari hasil penelitian siswa yang kemampuan dasarnya tinggi, ketika menyajikan data/informasi ke representasi gambar sudah benar dan tepat dengan memberikan tanda siku pada gambar persegi dan persegi panjang. Ketika menyelesaikan masalah yang melibatkan eskpresi matematis, siswa dalam menyelesaikan soal ekspresi matematis untuk penyelesaiannya sudah benar dan tepat, namun kurang lengkap karena tidak menuliskan diketahui dan ditanyakan saat menjawab soal tersebut. Ketika menuliskan langkah-langkah penyelesaian masalah matematika dengan kata-kata, siswa sudah memberikan jawaban yang benar dan tepat, hanya saja siswa tidak memberikan kesimpulan.

Siswa yang kemampuan dasarnya menengah, yaitu dilihat dari hasil penelitian siswa yang kemampuan dasarnya menengah, ketika menyajikan data/informasi ke representasi gambar sudah benar tetapi kurang tepat karena tidak memberikan tanda siku pada gambar persegi dan persegi panjang. Ketika menyelesaikan masalah yang melibatkan ekspresi matematis, siswa dalam menyelesaikan soal ekspresi matematis untuk penyelesaiannya sudah benar, tetapi siswa dalam menjawab soal tersebut tidak menuliskan rumus jajar genjang dan siswa hanya menuliskan jawabnnya saja, sebagian siswa dalam menjawab soal untuk penyelesaiannya kurang tepat, namun siswa menuliskan rumus luas layang-layang, siswa terlalu terburu-buru dalam menyelesaikan soal tersebut, sehingga jawabannya kurang tepat. Ketika menuliskan langkah-langkah penyelesaian masalah matematika dengan kata-kata, siswa sudah memberikan jawaban yang benar, tetapi kurang lengkap.

Siswa yang kemampuan dasarnya bawah, yaitu dilihat dari hasil penelitian siswa yang kemampuan dasarnya bawah, ketika menyajikan data/informasi ke representasi gambar kurang tepat karena tidak memberikan tanda siku pada gambar persegi dan persegi panjang, sebagian siswa dalam menggambar persegi dan persegi panjang kurang tepat. Ketika menyelesaikan masalah yang melibatkan ekspresi matematis, siswa dalam menyelesaikan soal ekspresi matematis untuk penyelesaiannya kurang tepat, siswa dalam menjawab soal tersebut tidak menuliskan rumus jajar genjang dan jawabannya kurang tepat, sebagian siswa dalam menjawab soal tersebut tidak menuliskan rumus layang-layang dan tidak memberikan jawaban. Ketika menuliskan langkah-langkah penyelesaian masalah matematika dengan kata-kata, siswa sudah memberikan jawaban kurang tepat dan kurang lengkap.

Pada penelitian ini, terlihat bahwa kurangnya pengetahuan dan pemahaman konsep berpengaruh pada representasi matematis yang dimiliki oleh siswa. Seseorang yang mempunyai intelegensi tinggi memiliki analogi yang matang untuk merepresentasikan suatu masalah. Dengan kata lain, ketika seseorang mempunyai intelegensi yang baik, dia akan mampu merepresentasikan suatu masalah dengan baik pula. Peneliti juga melihat representasi matematis siswa juga akan menentukan tepat atau tidaknya strategi yang digunakan dalam 
menyelesaikan soal. Ketika representasi yang disajikan benar, maka strategi yang digunakan untuk menemukan jawaban juga benar. Akan tetapi ketika representasi yang disajikan salah, maka strategi dan jawaban akhir yang ditemukan juga menjadi kurang tepat. Hal ini sesuai dengan Mustangin (yang mengatakan bahwa pemilihan representasi siswa sangat berperan dalam pengambilan keputusan strategi pemecahan masalah matematika yang tepat dan akurat. Keterkaitan antara kemampuan matematika dan sikap seseorang dalam menghadapi masalah dipengaruhi oleh faktor pembelajaran yang menuntut siswa menjadi aktif dalam berpikir dan berinteraksi, sehingga dapat meningkatkan kemampuan matematika yang menjadi harapan tujuan pembelajaran pada umumnya (Hendriana, Rohaeti, \& Hidayat, 2017).

\section{KESIMPULAN}

Dari hasil studi pendahuluan ini maka dapat disimpulkn bahwa tingkat kemampuan representasi matematik siswa SMPN di Karawang. Siswa yang memiliki tingkat kemampuan dasar kelompok atas dengan persantase $83 \%$, kemampuan representasi visualnya berada pada kategori tinggi, siswa sudah baik dalam menyelesaikan soal segi empat. Kemampuan representasi simbolnya berada pada kategori sedang dengan, siswa sudah menggunakan ekspresi matematis dalam menyelesaikan soal dengan menuliskan perhitungan yang digunakan. Kemampuan representasi verbalnya berada pada kategori sedang, siswa masih kurang lengkap karena belum mampu menyajikan penjelasan yang sesuai dan cenderung menggunakan representasi visual dan representasi matematis dalam menyelesaikan soal. Siswa yang memiliki tingkat kemampuan dasar kelompok menengah dengan persentase $72 \%$, kemampuan representasi visual dan simbolnya berada pada kategori sedang dan kemampuan representasi verbalnya berada pada kategori rendah. Siswa yang memiliki tingkat kemampuan dasar kelompok bawah dengan persentase $50 \%$, kemampuan representasi visualnya berada pada kategori sedang, kemampuan representasi simbolnya berada pada kategori rendah, kemampuan representasi verbalnya berada pada kategori sangat rendah.

\section{DAFTAR PUSTAKA}

Afrilianto, M. (2014). Strategi Formulate Share Listen Create Untuk Mengembangkan Kemampuan Mathematical Problem Posing Siswa SMP. Jurnal Ilmiah STKIP Siliwangi Bandung, 8, 21-28.

Effendi, L. A. (2012). Pembelajaran Matematika Dengan Metode Penemuan Terbimbing Untuk Meningkatkan Kemampuan Representasi Dan Pemecahan Masalah Matematis Siswa Smp. Jurnal Penelitian Pendidikan, 1-10.

Hendriana, H., Rohaeti, E. E., \& Hidayat, W. (2017). Metaphorical Thinking Learning and Junior High School Teachers' Mathematical Questioning Ability. Journal on Mathematics Education, 8(1), 55-64.

Hutagaol, K. (2013). Pembelajaran Kontekstual untuk Meningkatkan Kemampuan Representasi Matematis Siswa Sekolah Menengah Pertama. Jurnal Ilmiah Program Studi Matematika STKIP Siliwangi Bandung, 2(1), 85-99.

Laila, N., Hidayat, W., \& Hendriana, H. (2018). KEMAMPUAN REPRESENTASI MATEMATIS DAN KEAKTIFAN BELAJAR SISWA SMP. JPMI (Jurnal 
Pembelajaran Matematika Inovatif), 1(3), 395-400.

Mandur, K., Sadra, I. W., \& Suparta, I. N. (2013). Kontribusi Kemampuan Koneksi, Kemampuan Representasi, dan Disposisi Matematis terhadap Prestasi Belajar Matematika Siswa SMA Swasta di Kabupaten Manggarai. E-Journal Program Pascasarjana Universitas Pendidikan Ganesha Program Studi Pendidikan Dasar, 2.

Moka, S., Hendriana, H., \& Afrilianto, M. (2018). Kemampuan Representasi Matematik Siswa Kelas IX MTs pada Materi Bangun Ruang Sisi Lengkung dengan Penerapan Pendekatan Reciprocal Teaching. JPMI (Jurnal Pembelajaran Matematika Inovatif), 1(3), 259-268.

Rohaeti, E. E. (2012). Analisis pembelajaran konsep esensial matematika sekolah menengah melalui pendekatan kontekstual socrates. Jurnal Ilmiah Program Studi Matematika STKIP Siliwangi Bandung, 1(2), 186-191. 
772 Nurpadilah, Rohaeti\& Afrilianto, Kemampuan Representasi Matematis pada Materi .... 